\title{
EMPLACEMENT OF CREATIVE IT SPECIALISTS IN LATVIA
}

\author{
Svetlana Gribanova, Anna Ābeltina \\ Turiba University, Latvia \\ Svetlana.gribanova.p@gmail.com; anna.abeltina@gmail.com
}

\begin{abstract}
Current paper contains the research concerning the role and concentration of IT specialists in contemporary Latvia. It is based on theoretical findings about the location of creative class in certain areas that meet the requirements of technology, tolerance and talent. At the same time, the advantages of creative people staying in the area are undoubted. Creative class and, first of all, super-creative core of creative class bring economic and technological development into the area it is located at. The goal of the article is to examine areas of creative IT specialist concentration within Latvia.

The statistics and dynamics of IT position increase were examined and trends found. In order to define the role of IT specialists in Latvia, the allocations of IT specialists across the country were analysed. Herfindahl-Hirschman Index of Information and communication industry employee concentration was calculated. It was found that IT specialists in Latvia are extremely concentrated. Riga planning region accumulates $91.51 \%$ of all IT specialists in Latvia.

Key words: creative class, IT specialists, concentration, urbanization.
\end{abstract}

\section{Introduction}

Sustainable development demands equability of regions within the country in their access to resources, including information and communication technologies. These resources are provided by IT specialists living in the area. Along with access to information, IT specialists bring prosperity and development by giving economic benefits through business activity growth. As a part of creative class IT specialists develop the community making it a better place for living. Every country is interested in developing service sector and digital economy. Through IT technology companies, regions and countries become more productive in comparison with other economic subjects. This is why studying the emplacement of creative IT specialists in Latvian regions is extremely important.

Nowadays Information and communication technology sector takes the leading role all over the world. Post-industrial development is aimed at using IT specialists to provide Latvia with some competitive advantages in global economy. This is why the role of IT specialists in the structure of working force in Latvia has to be examined.

\section{Materials and Methods}

The research question of the article is finding out the areas of concentration of IT specialists in Latvia. According to the research question, the aim of the paper is to apply theoretical approach to the creative class concentration and analyse European and Latvian statistical data in order to evaluate the regions of allocation of IT specialists in Latvia. The research is based on secondary data drawn from previous research and statistical reports dated $2014-2016$.

Objectives of the article are:

- $\quad$ Estimate the significance and demography of IT business enterprises in EU through analysing the tendencies of development of IT enterprises;

- Evaluate theoretical studies concerning creative class concentration in certain areas. Different researches dedicated to the emplacement of creative IT specialists prove the mutual influence of creative class emplacement and regional development;

- Study the allocation of specialists in Information and communication sector in Latvia through the evaluation of contemporary statistic data;

Calculate concentration coefficient of IT specialists in Latvia. Herfindahl-Hirschman index is applied for this purpose.

In order to achieve these objectives, bibliographical sources are critically reviewed, statistical data is analysed and economic models are applied. Reviewing bibliographical sources through studying and comparing relevant theories let us build the basis for empiric research such as statistical data evaluation. Official statistical sources were studied and organized to provide the proof of theoretical conclusions. Herfindahl-Hirschman index, which is usually applied for estimation of market monopolization, was applied to estimate IT specialist concentration.

\section{The Significance of IT Specialists in the European Union}

The Information and communication technology (ICT) sector represents $4.8 \%$ of European economy. Investments in ICT account for $50 \%$ of productivity growth in the united Europe. ICT sector also generates $25 \%$ of the total business expenditure in Research and Development (ICT Research and Innovation, 2017). Statistical data show that both the number of active ICT enterprises and the number of IT specialists continually grow (Rosetti, 2017).

Obviously, the European leaders among ICT enterprises are United Kingdom, Germany and France. Latvia holds less than $1 \%$ of ICT enterprises of EU. 


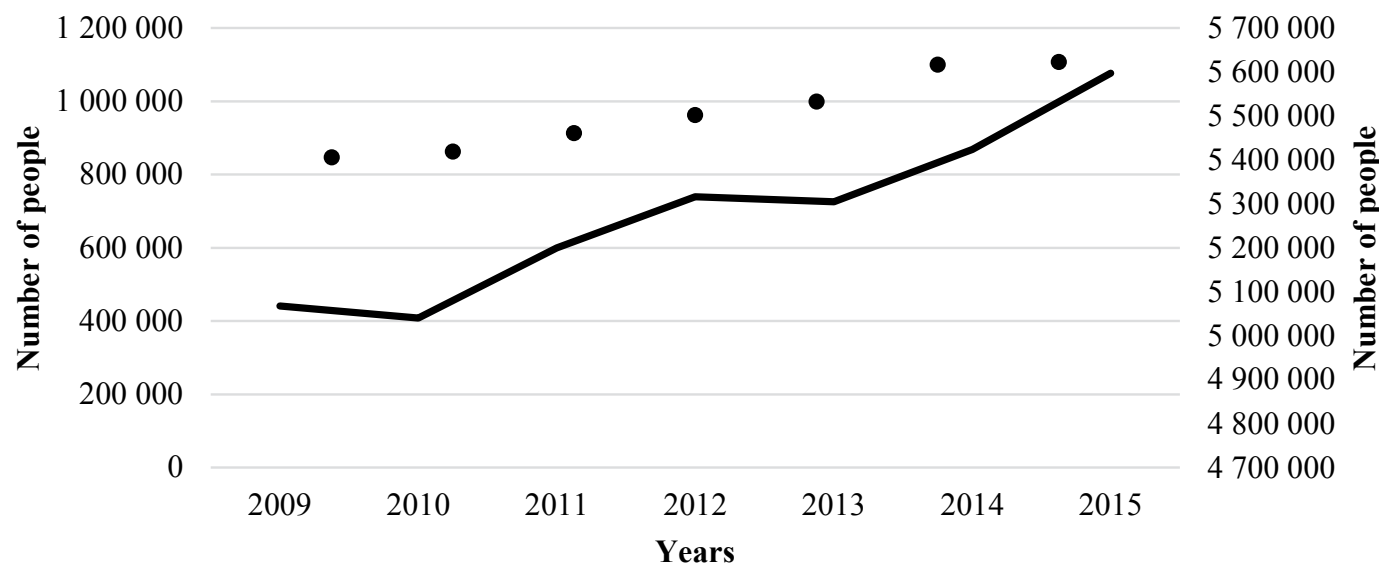

Number of employees in the population of active enterprises in ICT

- Number of population of active enterprises in ICT

Source: Rosetti, F. (2017). The Business Demography of the ICT Sector in Europe.

Figure 1. Evolution of the number of active enterprises and employees in the Information and communication technology sector - Total (ICT) in the EU from 2009 to $2015^{1}$.

However, it is clear from the Figure 2 that the number of births of new enterprises exceeds the number of their deaths (Rosetti, 2017). This is a very positive trend reflecting the distribution of IT technologies in Latvia.

Most employees of ICT enterprises are located in UK, Germany, France, Italy and Spain. These are countries that are considered to be the most economically and technologically developed in the EU. It supports the idea of Rosenau about fragmentation when IT specialists double the movement of both integration and fragmentation (Rosenau, 2003). On the one hand, they concentrate in global IT centers that provide them with better working and living environment. But on the other hand, the diversity of such centers makes IT labor force spread out. It raises a question whether creative IT specialists are accumulated in these countries because they are thriving or prosperity of these countries is generated by creative IT specialists.

\section{Theoretical Justifications of Creative Class} Concentration in Certain Areas

IT specialists represent ambiguous layer of creative class. According to Florida's division, two cores of creative class are super-creative core and the creative professionals. Super-creative core is responsible for creating new products, knowledge and know-how, while creative professionals work in knowledge intensive industries (Florida, 2002). IT specialists can operate in both cores: creating new knowledge and developing new software products as a super-creative class, and maintaining information system as creative professionals.
According to the human capital theory, the cities and creative IT specialists form a vicious circle: regional growth is stimulated by highly educated creative people and creative people are attracted by opportunities of highly developed regions. According to Castel's Network Society theory, IT revolution created new conditions that set both constraints and possibilities for the new society (Castells, 2000). Creative Class Theory developed by Florida brakes this vicious circle. It states that it is creative educated people who choose territory and make it a center for innovations and economic growth. One proof of this theory is East Berlin. Recent statistical data show that $14.8 \%$ of specialists employed in professional and related occupations (IT, engineering, art, education, legal and health) in the USA are foreign born (Foreign-born Workers: Labor Force Characteristics 2016, 2017). After the fall of the Berlin wall creative talented people moved into the city and quickly turned it into one of the fast developing regions in the world. The chosen territory should meet 3 T's condition: technology, tolerance and talent (Florida, 2004). However, the human capital theory strikes back, arguing that Florida's "creative capital" is formed by highly educated individuals and there is no novelty in stating that educated people drive the region's economy development (Gleaser, 2005). Pratt argues that "creativity is a magic bullet that leads to competitiveness" (Pratt, 2009).

To determine the urbanistic context within which the growth of innovation and creativity take place, 'the creative city' concept appeared (Kong \& O’Connor, 2009). In accordance with Lobo at al.

${ }^{1}$ Updated data Retrieved July 17, 2018, from: http://appsso.eurostat.ec.europa.eu/nui/submitViewTableAction.do. 


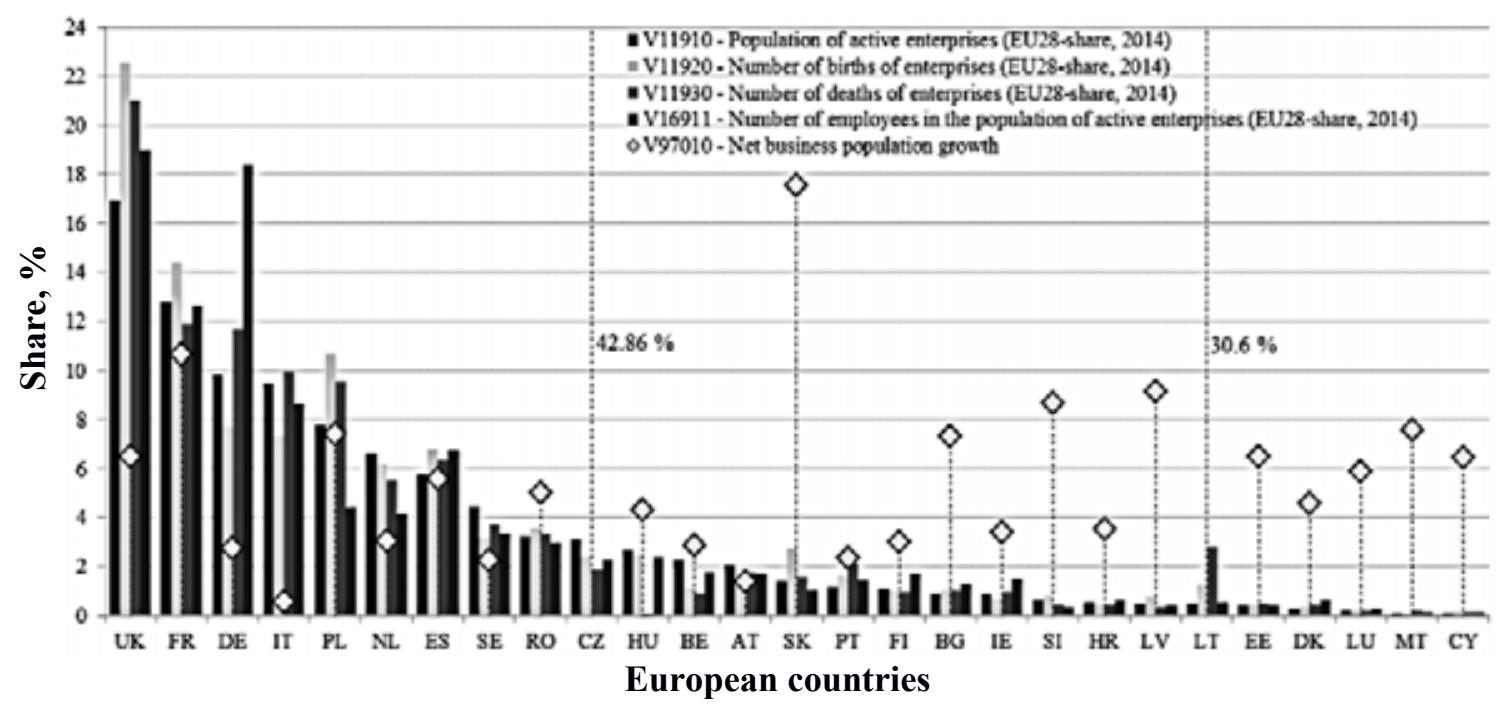

Source: Rosetti, F. (2017). The Business Demography of the ICT Sector in Europe.

Figure 2. Member States by their shares (\%) of the EUactive ICT enterprises in 2014.

research findings, highly productive metropolitan areas tend to have higher levels of educated creative individuals (defined as creative professionals by Florida) but they do not necessarily have high levels of inventive labor (defined as super-creative class by Florida).

Lobo at al. also concluded that the growth of regional productivity is caused by super-creative class while creative professionals have negligible or negative effect (Lobo et al., 2014). Hence, it is possible to deduce that creative professionals represent demand for development while super-creative class perform as a source of development. Mommaas mentions that professionals oriented towards economic success and technology prefer more homogeneous suburbs, while art- and culture-oriented professionals choose informality and diversity within the city (Mommaas, 2009).
In order to attract creative class, the areas compete with each other and build place- marketing strategies. By using marketing tools they try to satisfy the demand of creative specialists in urban goods and services (Braun, 2008). There are empiric researches proving an obvious correlation among the residence of creative class in the area and development of cultural services, diversity and economy in European context (Andersen et al., 2008; Clifton, 2008).

Division of creative class as a solid group into subgroups with different preferences and priorities concerning emplacement is justified by Bjørn Asheim and Høgni Kalsø Hansen. Depending on affiliation of creative class to analytical, synthetic, and symbolic knowledge, sub-group location preferences differ (Asheim \& Hansen, 2009). IT specialists belong to synthetic knowledge sub-group and have different preferences than artists from symbolic knowledge sub-

Table 1

Occupied posts by kind of economic activity on average per year

\begin{tabular}{|l|c|c|c|c|c|c|c|c|}
\hline & \multicolumn{2}{|c|}{2005} & \multicolumn{2}{c|}{2010} & \multicolumn{2}{c|}{2015} & \multicolumn{2}{c|}{2016} \\
\cline { 2 - 9 } & $\begin{array}{c}\text { Occupied } \\
\text { posts }\end{array}$ & $\begin{array}{c}\% \text { of } \\
\text { Total }\end{array}$ & $\begin{array}{c}\text { Occupied } \\
\text { posts }\end{array}$ & $\begin{array}{c}\% \text { of } \\
\text { Total }\end{array}$ & $\begin{array}{c}\text { Occupied } \\
\text { posts }\end{array}$ & $\begin{array}{c}\% \text { of } \\
\text { Total }\end{array}$ & $\begin{array}{c}\text { Occupied } \\
\text { posts }\end{array}$ & $\begin{array}{c}\% \text { of } \\
\text { Total }\end{array}$ \\
\hline Total & 919469 & 100.00 & 776742 & 100.00 & 883759 & 100.00 & 887310 & 100.00 \\
\hline $\begin{array}{l}\text { Information and } \\
\text { communication }\end{array}$ & 18008 & 1.96 & 18190 & 2.34 & 27800 & 3.15 & 30456 & 3.43 \\
\hline $\begin{array}{l}\text { Programming and } \\
\text { broadcasting activities }\end{array}$ & 1398 & 0.15 & 1516 & 0.20 & 1616 & 0.18 & 1590 & 0.18 \\
\hline $\begin{array}{l}\text { Computer programming, } \\
\text { consultancy and related } \\
\text { activities }\end{array}$ & 3654 & 0.40 & 5498 & 0.71 & 11924 & 1.35 & 13432 & 1.51 \\
\hline Information service activities & 909 & 0.10 & 1857 & 0.24 & 5687 & 0.64 & 6848 & 0.77 \\
\hline
\end{tabular}

Source: Author's calculations based on the data of Central Statistical Bureau of Latvia. 
group or scientists in analytical knowledge sub-group. So, for IT specialists as part of synthetic knowledge sub-group, business climate is more important than people climate (Asheim \& Hansen, 2009).

Wuwei tries to show the relations between creative class, creative district and creative cluster putting them all at the same level in process of creating creative community (Wuwei, 2011).

For most IT specialists living in the cities is not a matter of choice. IT companies tend to cluster (Florida,
2004). It is conditioned by necessity to mobilize IT resources rapidly and be able to catch the novelties as soon as they appear. However, Florida's theory has some limitations in case of EU. Compared to the USA, European countries face language and cultural differences that do not allow the creative class flow to be so unordered. Competition between the cities on the national level in Europe is less intense, social benefits and women's participation in labor market rate is higher (Asheim, 2009). This is why Florida's

Occupied posts by region and kind of economic activity; average per year, 2016

Table 2

\begin{tabular}{|c|c|c|c|c|c|c|c|c|c|c|c|c|c|}
\hline & \multicolumn{2}{|c|}{$\begin{array}{l}\text { Riga region } \\
\text { (Riga) }\end{array}$} & \multicolumn{2}{|c|}{$\begin{array}{l}\text { Pierīga } \\
\text { region }\end{array}$} & \multicolumn{2}{|c|}{$\begin{array}{l}\text { Vidzeme } \\
\text { region }\end{array}$} & \multicolumn{2}{|c|}{$\begin{array}{c}\text { Kurzeme } \\
\text { region }\end{array}$} & \multicolumn{2}{|c|}{$\begin{array}{c}\text { Zemgale } \\
\text { region }\end{array}$} & \multicolumn{2}{|c|}{$\begin{array}{l}\text { Latgale } \\
\text { region }\end{array}$} & \multirow[t]{2}{*}{$\begin{array}{c}\text { Latvia } \\
\text { Total }\end{array}$} \\
\hline & 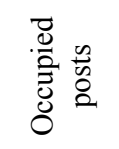 & 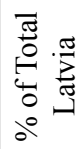 & 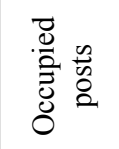 & 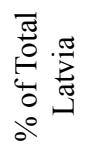 & 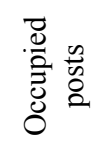 & 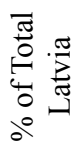 & 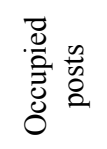 & 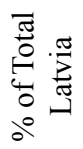 & 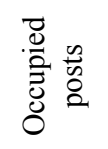 & 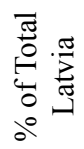 & $\begin{array}{l}\overrightarrow{0} \\
\stackrel{0}{0} \\
\stackrel{2}{0} \\
\stackrel{0}{0} \\
0 \\
0\end{array}$ & 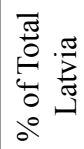 & \\
\hline Total & 487085 & 54.89 & 133940 & 15.10 & 57455 & 6.48 & 76209 & 8.59 & 65055 & 7.33 & 67566 & 7.61 & 887310 \\
\hline 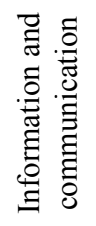 & 25535 & 83.84 & 2337 & 7.67 & 400 & 1.31 & 983 & 3.23 & 439 & 1.44 & 762 & 2.50 & 30456 \\
\hline 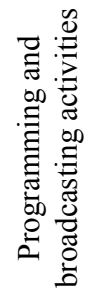 & 1444 & 90.8 & 21 & 1.32 & 36 & 2.26 & 39 & 2.45 & 37 & 2.33 & 13 & 0.82 & 1590 \\
\hline 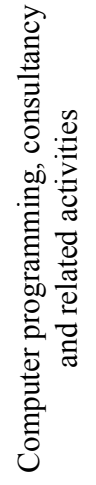 & 11075 & 82.45 & 1477 & 11.0 & 141 & 1.05 & 309 & 2.30 & 170 & 1.27 & 261 & 1.94 & 13432 \\
\hline 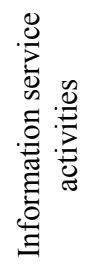 & 6000 & 87.6 & 410 & 6.0 & 70 & 1.02 & 242 & 3.53 & 51 & 0.74 & 75 & 1.10 & 6848 \\
\hline
\end{tabular}

Source: Author's calculations based on the data of Central Statistical Bureau of Latvia. 
theory should not be taken as given in the European context.

Estimating creative class concentration in certain areas, R. Florida provides top five regions in the USA: Washington D.C., Boston, Austin, the Research Triangle and San Francisco (Florida, 2004). These areas are also characterized by highest Inequality Index that compares the wages of creative sector workers to those in the manufacturing sectors. Creative areas outside the United Stated include Toronto and Vancouver in Canada, Sydney and Melbourne in Australia, Dublin, London, Helsinki, Amsterdam, and Copenhagen in Europe. However, now the trend is switching to China, India and Russia. For example, a report on Shanghai's digital content industry shows that the industry employed almost 3 times more people in 2006 in comparison with 2002 (Wuwei, 2011).

Nowadays the EU government understands the necessity of using the potential of creative class for developing innovations. HORIZON 2020 Work Programme 2016 - 2017 highlights that one of the challenges of technological development in Europe is widening and accelerating the exchange of ideas, knowledge and skills between super-creative class and entrepreneurs (Horizon 2020).

\section{Concentration of IT Specialists in Latvia}

Post-industrial era demands IT specialists as one of core professionals providing technological development of the country. In 2017 Latvia was ranked 33rd in Global Innovation Index and further development is possible through enlarging and spreading creative IT specialists through the country (The Global Innovation Index, 2017). Statistical data proves that the number of employed specialists in Information and communication sector increased by $69 \%$ in 2016 in comparison with 2005. The fastest growth occurred since 2010 and it is still continuing. Thus, the growth of the number of specialists in Information and communication sector in 2016 was $9.55 \%$ compared to 2015 . Latvian statistical data perfectly matches previous European research by which "the rank-size distribution of the creative class indicates a greater proportionate growth than that of the general population's" (Lorenzen \& Andersen, 2009). This research also indicates that it has greater diseconomies of small cities (Lorenzen \& Andersen, 2009).

The most noticeable growth took place in computer programming, consultancy and related activities, as well as Information service activities. Programming and broadcasting activities did not experience dramatic changes.

Theoretical findings studied above showed that creative IT specialists need convenient environment and they tend to congregate in certain areas. The analysis of Latvian statistics proves this statement. Riga region accumulates only $54.89 \%$ of total posts. However $83.84 \%$ of all posts in Information and communication sector are concentrated in Riga region.

The allocation of IT specialists is shown in Figure 3. Riga planning region, which includes Pieriga region and Riga itself, contains $91.51 \%$ of total IT specialists of Latvia. The concentration of IT specialists in Kurzeme and Latgale regions exceeds $2 \%$, while Vidzeme and Zemgale regions accumulate less than $2 \%$ of Latvia's IT Specialists. The concentration of

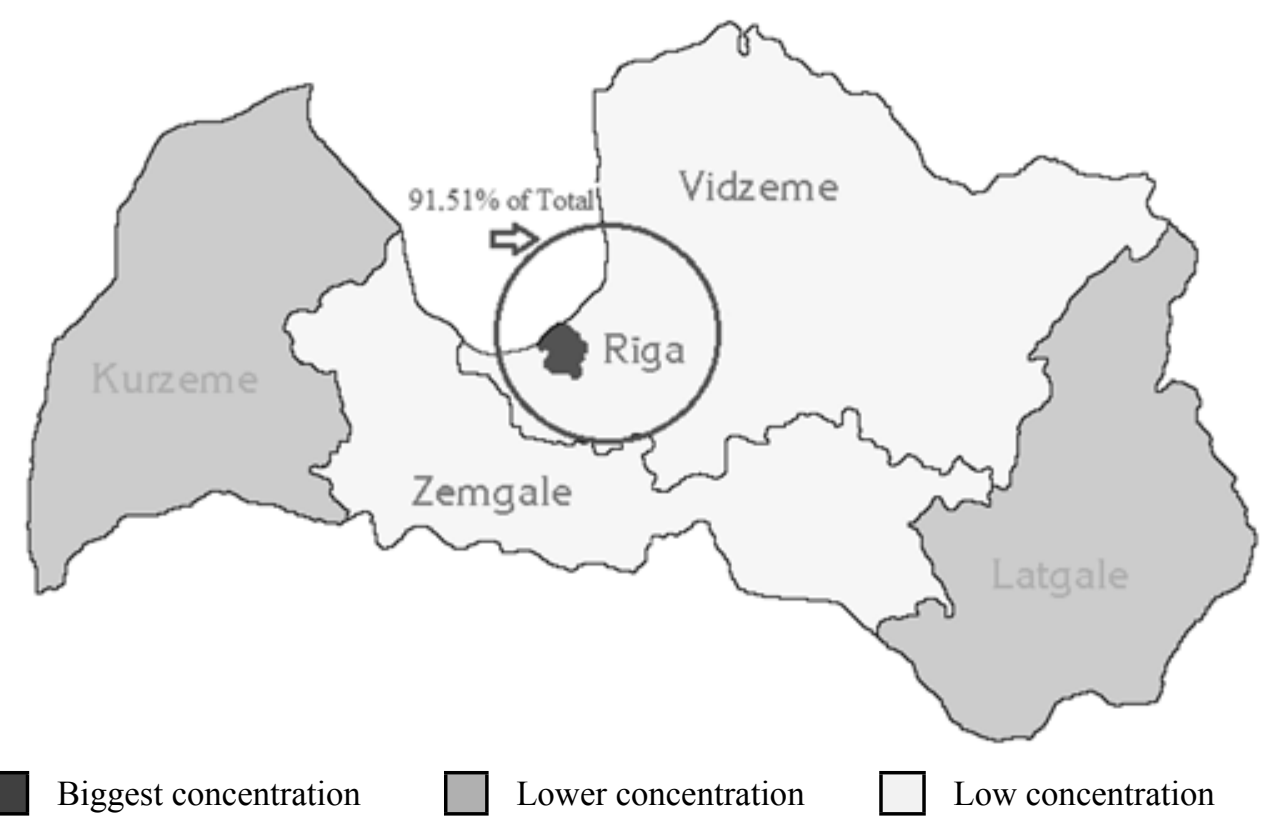

Figure 3. Concentration of specialists in Information and communication sector in Latvia. 
creative IT specialists near Riga corresponds with the European creative cities concept, where cities are viewed as post- and para-national concept (Corijn, 2009).

In order to define the extent of concentration Herfindahl-Hirschman index may be applied.

$$
\mathrm{HH}=\sum_{i=1}^{N} s_{i}^{2}
$$

For IT specialist concentration in Latvia:

$$
\begin{aligned}
& \mathrm{HH}=0.8384^{2}+0.0767^{2}+0.0131^{2}+0.0323^{2}+ \\
& +0.0144^{2}+0.025^{2}=0.72
\end{aligned}
$$

Herfindahl-Hirschman index above 0.25 indicated high concentration. Concentration of Latvian IT specialists is extremely high.

There are various explanations of the high concentration of creative IT specialists in large urban areas. The most common one: "creative begets more creative" (Lorenzen \& Andersen, 2009). According to social network theory (Watts, Dodds, \& Newman, 2002), the larger the city and larger the presence of creative class in the city, the more links they possess to attract more creative people. (Uzzi \& Spiro, 2005). This raises a question: what should small cities do? Within European Union in terms of open borders even Riga with its over 640 thousand population can be considered relatively small. Lewis and Donald believe that small cities should rely on "livability" and "sustainability" in their attempts to attract creative IT specialists (Lewis \& Donald, 2010). They should attract the creative class with the "quality of life" and "authenticity" (Rich, 2013). Hereby, developing regions of Latvia by attracting IT specialists seems possible.

\section{Results and Discussion}

Even though it was proved that in case of Latvia creative IT specialists concentrate near urban agglomerations, the compliance of these areas with 3
Ts (tolerance, talent and technology) was not studied and should be covered in further research.

Theoretical dilemma concerning precedence of creative class location or technological and economic development received no empiric findings. This correlation may beathe subject of a separate paper.

Another topic for futher studies is the relation of concentration of IT specialists and IT enterprises to the concentration of specialists and enterprises of any type in certain areas. It might be interesting to compare the share of IT specialists and enterprises among overall employees and enterprises in certain areas and to receive both relative and absolute indicators.

\section{Conclusions}

Theoretical and methodological analysis performed for this paper allowed to reach the following conclusions:

1) ICT sector is fast and permanently growing sector within European economy;

2) Latvia's ICT sector is developing as the number of births of new enterprises exceeds the number of their deaths;

3) Cities and creative IT specialists form a vicious circle: regional growth is stimulated by highly educated creative people and creative people are attracted by opportunities provided by highly developed regions. Opinions in support of both theories were provided;

4) The role of IT specialists in Latvia occupied posts was evaluated;

5) According to Herfindahl-Hirschman index, the IT professionals are extremely concentrated in Riga planning region.

The results of the research may be useful for regional authorities in their attempts to increase regional attractiveness by attracting IT specialists. In order to provide steady development, other regions in Latvia should create working places and attractive environment for creative IT specialists.

\section{References}

1. Andersen, K.V., Hansen, H.K., Isaksen, A., \& Raunio, M. (2008). Nordic city regions in the creative class debate: Putting the creative class thesis to a test. In The urban turn-and the location of economic activities, Ph.D. thesis, ed. H.K. Hansen. Lund, Sweden: Lund University. pp. 165-198.

2. Asheim, B. (2009). Guest Editorial: Introduction to the Creative Class in European City Regions, Economic Geography, 85:4, pp. 355-362.

3. Asheim, B., \& Hansen, H.K. (2009). Knowledge bases, talents, and contexts: On the usefulness of the creative class approach in Sweden. Economic Geography 85, pp. 425-442.

4. Braun, E. (2008). City Marketing: Towards an Integrated Approach (No. EPS-2008-142-ORG). ERIM Ph.D. Series Research in Management. Erasmus Research Institute of Management.

5. Castells, M. (2000). The Rise of the Network Society: The Information Age: Economy, Society and Culture, Vol. 1. Oxford, UK, 594 p.

6. Central Statistical Bureau of Latvia. Retrieved February 2, 2018, from: www.csb.gov.lv/en/statistikastemas/population-key-indicators-30624.html. 
7. Clifton, N. (2008). The "creative class" in the UK: An initial analysis. Geografiska Annaler: Series B, Human Geography, 90, pp. 63-82. DOI: 10.1111/j.1468-0467.2008.00276.x.

8. Corijn, E. (2009). Urbanity as a political project: Towards post-national European cities. In Creative Economies, Creative Cities: Springer, Dordrecht, pp. 197-206.

9. Glaeser, E. (2005). Review of Richard Florida's The Rise of the Creative Class. Regional science and urban economics, 35(5), pp. 593-596, DOI: 10.1016/j.regsciurbeco.2005.01.005.

10. Global Innovation Index 2017(2017). RetrievedFebruary 1,2018, from: https://www.globalinnovationindex. org/gii-2017-report.

11. Florida, R. (2002). The Rise of the Creative Class: and how it's transforming work, leisure, community and everyday life. New York: Basic Books.

12. Florida, R. (2004). Cities and the Creative Class. New York: Basic Books.

13. Foreign-born Workers: Labor Force Characteristics - 2016. Bureau of Labor Statistics. U.S. Department of Labor (2017). Retrieved February 3, 2018, from: www.bls.gov/cps.

14. Horizon 2020. Work Programme 2016 - 2017. European Commission. Retrieved January 29, 2018, from: http://ec.europa.eu/research/participants/data/ref/h2020/wp/2016_2017/main/h2020-wp1617-leit-ict_ en.pdf.

15. ICT Research and Innovation (2016). Retrieved January 20, 2018, from: https://ec.europa.eu/programmes/horizon2020/en/area/ict-research-innovation.

16. Kong, L., \& O’Connor, J. (2009). Creative Economies, Creative Cities. pp. 1-5. The GeoJournal Library, vol 98. Springer, Dordrecht, DOI: 10.1007/978-1-4020-9949-6_1.

17. Lewis, N.M., \& Donald, B. (2010). A new rubric for "creative city" potential in Canada's smaller cities. Urban Studies, 47, 29-54.

18. Lobo, J., Mellander, C., Stolarick, K., \& Strumsky, D. (2014). The Inventive, the Educated and the Creative: How Do They Affect Metropolitan Productivity? Industry and Innovation, Vol. 21, No. 2, pp. 155-177, DOI: $10.1080 / 13662716.2014 .896602$.

19. Lorenzen, M., \& Andersen, K. (2009). Centrality and Creativity: Does Richard Florida's Creative Class Offer New Insights into Urban Hierarchy?, Economic Geography, 85:4, pp. 363-390.

20. Pratt, A.C. (2009). Policy transfer and the field of the cultural and creative industries: learning from Europe? In L. Kong, \& J. O'Connor (Eds.), Creative Economies, Creative Cities: Asian-European Perspectives. Heidelberg, Germany: Springer Finance, pp. 9-23.

21. Mommaas, H. (2009). Spaces of culture and economy: Mapping the cultural-creative cluster landscape. In Creative economies, creative cities: Springer, Dordrecht, pp. 45-59.

22. Rich, M. (2013). "From coal to coal": the creative class, social capital, and the revitalization of Scranton. Journal of Urban Affairs, 35, pp. 365-384.

23. Rosenau, J. (2003). Distant Proximities: Dynamics Beyond Globalization. Princeton, NJ: Princeton University Press.

24. Rosetti, F. (2017). The Business Demography of the ICT Sector in Europe. JRC Science for Policy Report. Retrieved February 8, 2018, from: http://publications.jrc.ec.europa.eu/repository/bitstream/JRC106589/ jrc106589(1).pdf.

25. Uzzi, B., \& Spiro, J. (2005). Collaboration and creativity: The small world problem. American Journal of Sociology 2, pp. 447-504. DOI: 10.1086/432782.

26. Watts, D.J., Dodds, P.S., \& Newman, M.E.J. (2002). Identity and Search in Social Networks. Science, 296, pp. 1302-1305. DOI: 10.1126.1070120.

27. Wuwei, Li. (2011). How Creativity Is Changing China, ed. M. Keane; trans. M. Keane, H. Li, and M. Guo (London: Bloomsbury Academic, 2011), 36 p. 